\title{
Cyanobacteria in wetlands of the industrialized Sambalpur District of India
}

\author{
Pratibha Rani Deep, Shantanu Bhattacharyya and Binata Nayak
}

\begin{abstract}
Background: Cyanobacteria are common components of phytoplankton communities in most freshwater ecosystems. Proliferations of cyanobacteria are often caused by high nutrient loading, and as such can serve as indicators of declining water quality. Massive industrialization in developing countries, like India, has polluted fresh water bodies, including wetlands. Many industries directly discard their effluents to nearby water sources without treatment. In the Sambalpur District of India effluents reach the reservoir of the worlds largest earthen dam i.e Hirakud Dam. This study examines cyanobacteria communities in the wetlands of Sambalpur District, Odisha, India, including areas subjected to industrial pollution.

Result \& Discussion: The genera Anabaena, Oscillatoria, Chroococcus, Phormidium were dominant genera of polluted wetlands of Sambalpur districts. A positive correlation was found between total cyanobacterial species and dissolved oxygen levels, but cyanobacterial diversity was inversely related to BOD, COD, TSS, and TDS. High dissolved oxygen content was also associated with regions of lower cyanobacteria biomass.

Conclusion: Cyanobacterial abundance was positively correlated to content of oxidisable organic matter, but negatively correlated to species diversity. Lower dissolved oxygen was correlated to decreased diversity and increased dominance by Anabaena, Oscillatoria, Chroococcus, Phormidium species, observed in regions characterized by deteriorated water quality.
\end{abstract}

Keywords: Wetlands, Cyanobacteria, Eutrophication, Industrialization, Pollution

\section{Background}

Wetlands support a wide array of flora and fauna and deliver many ecological, climatic and societal functions. Scientists often refer to wetlands as the "kidneys" of the earth. However, many wetlands are subjected to urban and industrial pollution which disturb the aquatic ecosystem. Sambalpur is one of the main cultural and business centres of Odisha, India. It lies between $20^{\circ} 30^{\prime}$ $22^{\circ} 30^{\prime} \mathrm{N}$ latitude and $83^{\circ} \mathrm{E}-85^{\circ} 1^{\prime}$ 'longitudes with a total geographical area of $6,698 \mathrm{~km}^{2}$ Figure 1 . The Hirakud reservoir in Sambalpur was built primarily for hydropower generation, but is also used for irrigation, fisheries and drinking water. Sambalpur contains various freshwater ecosystem types, including lakes, reservoirs, ponds and wetlands. Cyanobacteria have been shown to be key primary producers at the base of the food web of many of these types of systems, i.e. freshwater (Muthukumar et al.,

\footnotetext{
*Correspondence: binata_bga@yahoo.com

CyanoLab, School Of Life Sciences, Sambalpur University, Jyoti Vihar, Burla, Sambalpur, Odisha 768019, India
}

[1], paddy fields (Bhattacharyya et al., [2], soils (Adhikary [3], desert (Bhatnagar et al., [4], temple (Deepa et al., [5] estuaries (Palleyi, [6], hotspring and marine hypersaline (Aharon et al., [7], Komarek et al., [8]. However, large proliferations of cyanobacteria are often caused by high nutrient loading, and therefore can be indicators of declining water quality (Rivas et al., [9]; Garcia et al., [10], which can be associated with a range of problems, such as low oxygen levels and the production of algal toxins (Komarek, [11]. Anthropogenically-driven increase in eutrophication and pollution have led to increases in the frequency and intensity of cyanobacteria blooms in ecosystems worldwide (Hecky [12]; Rivas et al., [9]; Garcia et al., [10].

This investigation focused on determining cyanobacterial composition and diversity in wetland ecosystems under the influence of industrial pollution in Sambalpur, India. Little information is available on cyanobacteria in wetlands of this region. In Orissa many researchers (Ghadai et al., [13]; Dey et al., [14,15]; Prasanna and Nayak [16]; Sahu [17]; Adhikary [3] have focused on cyanobacteria in rice fields. Dey and Bastia [15]; Dash et 


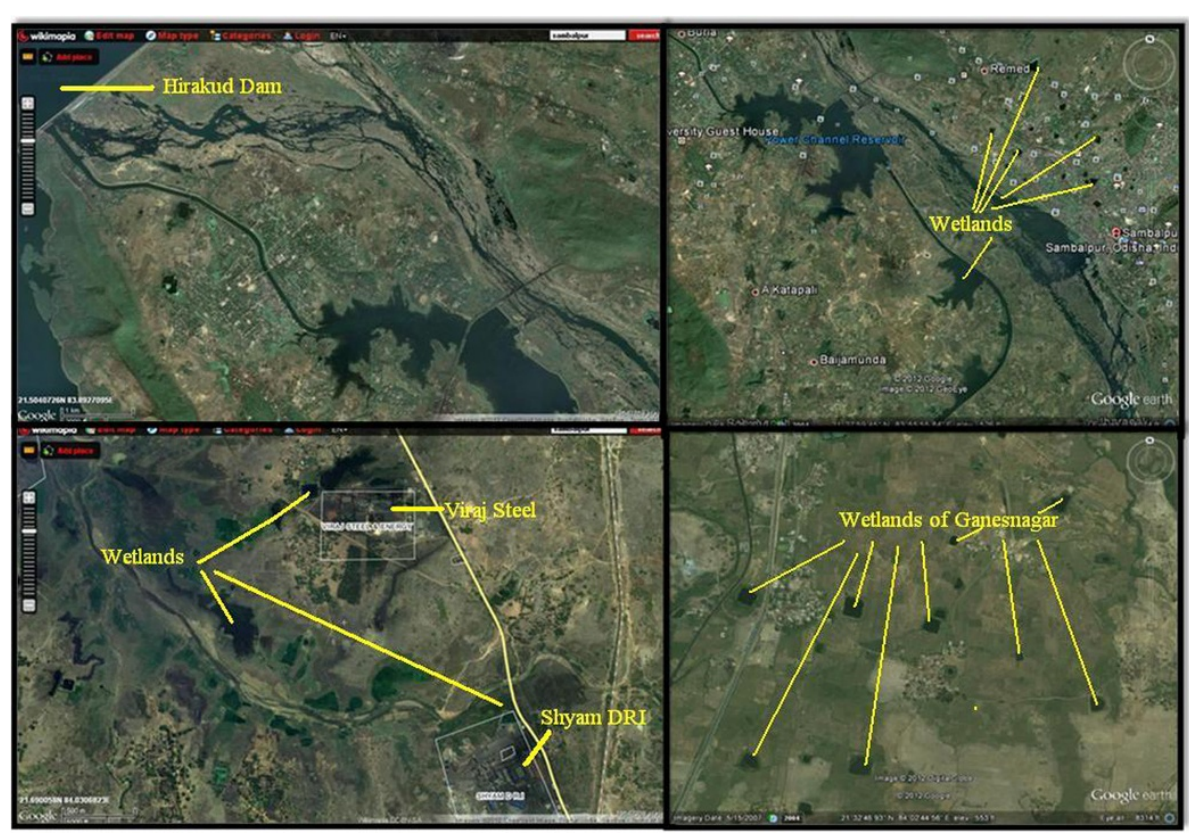

Figure 1 Different wetlands of Sambalpur Districts and nearby area of Hirakud Dam. Photo taken from Wikimapia (left) and Google earth (right).

al., [18] have studied algal flora of Simlipal biosphere. In the last five years, about 40 iron factories have been established in Sambalpur and its neighboring Jharsuguda district. In addition, a Super-thermal power plant, a paper mill and several cement factories are located in these two districts. Open cast coal mines of the Mahanadi coal fields are located in Western Orissa which includes Sambalpur, Jharsuguda and Sundargarh districts. Many of these industries discharge untreated water into local channels which drain into Hirakud reservoir. The municipal wastes of cities of this region also mix into the Mahanadi, the main river of this region. This study was carried out to provide important missing data needed to define algal flora within impacted wetland ecosystems of this region Das [19].

\section{Results and discussion}

During the present investigation water samples were collected from 10 sites in wetland and stagnant water bodies associated with different industrial applications. The physicochemical properties of water of all site are described in Table 1 including $\mathrm{pH}$, total suspended solids (TSS), total dissolved dolids (TDS), dissolved oxygen (DO), biological oxygen demand (BOD), chemical oxygen demand (COD),

Table 1 Physiochemical properties of water at different location

\begin{tabular}{lllllllll}
\hline Sampli ng point & $\mathbf{p H}$ & TSS (Mg/l) & TDS (Mg/l) & DO (Mg/l) & BOD (Mg/l) & COD (Mg/l) & NO3 (Mg/l) & PO4 (Mg/l) \\
\hline Site1 & $8.12 \pm 0.04$ & $312 \pm 14$ & $562 \pm 12$ & $6.2 \pm 0.5$ & $1.8 \pm 0.02$ & $20.4 \pm 1.1$ & $24 \pm 3$ & $18 \pm 3$ \\
Site2 & $7.13 \pm 0.2$ & $32 \pm 4.5$ & $174 \pm 10.5$ & $8.4 \pm 1.12$ & $0.6 \pm 0.03$ & $10.2 \pm 2$ & $16 \pm 2.2$ & $12 \pm 2$ \\
Site3 & $7.22 \pm 0.02$ & $68 \pm 6$ & $150 \pm 25$ & $7.5 \pm 0.04$ & $0.6 \pm 0.02$ & $13.2 \pm 1.2$ & $18 \pm 0.6$ & $14 \pm 1.2$ \\
Site4 & $7.51 \pm 0.06$ & $41 \pm 2.6$ & $132 \pm 11$ & $9.1 \pm 0.15$ & $0.4 \pm 0.1$ & $8.1 \pm 0.06$ & $9 \pm 1.2$ & $8 \pm 0.08$ \\
Site5 & $7.92 \pm 0.04$ & $364 \pm 12$ & $840 \pm 15$ & $5.2 \pm 0.22$ & $1.6 \pm 0.14$ & $18.6 \pm 0.18$ & $22 \pm 1.06$ & $34 \pm 1.8$ \\
Site6 & $7.32 \pm 0.12$ & $22 \pm 1.6$ & $160 \pm 6$ & $8.8 \pm 0.3$ & $0.4 \pm 0.06$ & $9.3 \pm 0.3$ & $18 \pm 1.4$ & $16 \pm 0.8$ \\
Site7 & $7.91 \pm 0.05$ & $180 \pm 5.6$ & $241 \pm 4$ & $7.2 \pm 0.4$ & $0.6 \pm 0.01$ & $8.2 \pm 0.21$ & $12 \pm 2.04$ & $10 \pm 1$ \\
Site8 & $8.21 \pm 0.11$ & $62 \pm 2$ & $188 \pm 6$ & $8.0 \pm 0.6$ & $0.9 \pm 0.3$ & $10.4 \pm 0.06$ & $14 \pm 0.8$ & $15 \pm 2$ \\
Site9 & $7.98 \pm 0.03$ & $170 \pm 2.8$ & $364 \pm 11$ & $7.7 \pm 0.02$ & $0.4 \pm 0.05$ & $9.2 \pm 0.06$ & $16 \pm 0.8$ & $18 \pm 2.0$ \\
Site10 & $7.60 \pm 0.04$ & $14 \pm 1.2$ & $72 \pm 6$ & $11.2 \pm 0.3$ & $0.4 \pm 0.16$ & $7.4 \pm 0.6$ & $22 \pm 1.0$ & $7 \pm 0.06$
\end{tabular}

Site1: Paddy Field water near SHYAM DRI Site2: Pond water Near Aryan Ispat and steel Pvt. Limited. Site3: Nearby wet lands of Viraj Steel Pvt. Ltd Site4: Stagnant water near Kherual bridge of M/s Bhusan Power and Steel Ltd. Site5: Paddy Field water near M/s Bhusan Power and Steel Ltd. Site6: Pond water near the Rengali WESCO office Site7: Water from local nallah near Debaipali Site8: Pond water of Sason village Site9: Pond water near Ganesh Nagar. Site 10. Guest House pond and nearby wetlands of Sambalpur University. 
phosphate $\left(\mathrm{PO}_{4}\right)$ and nitrate $\left(\mathrm{NO}_{3}\right)$ content. In all the study sites, $\mathrm{pH}$ of water was in the alkaline range of 7.13 to 8.21. The relationship between alkaline conditions and cyanobacteria has been previously noted by several researchers Nayak and Prasanna [20]; Verma and Mohanty [21]. Mean TSS concentrations ranged from $14 \mathrm{Mg} / \mathrm{l}$ at Site 10 to 364 $\mathrm{Mg} / \mathrm{l}$ at Site 5 . Mean TDS ranged from $76 \mathrm{Mg} / \mathrm{l}$ at Site 10 to $840 \mathrm{Mg} / \mathrm{l}$ at Site 5 . Mean dissolved oxygen levels ranged from $5.2 \mathrm{Mg} / \mathrm{l}$ at Site 5 to $11.2 \mathrm{Mg} / \mathrm{l}$ at Site 10. Mean BOD values ranged from $0.4 \mathrm{Mg} / \mathrm{l}$ Sites $4,6,9$ and 10 to $1.8 \mathrm{Mg} /$ $\mathrm{l}$ at Site 1. Mean COD values ranged from $7.4 \mathrm{Mg} / \mathrm{l}$ at Site 10 to 20.4 at Site 1 . Mean nitrate $\left(\mathrm{NO}_{3}\right)$ concentrations ranged from $9 \mathrm{Mg} / \mathrm{l}$ at Site 4 to $24 \mathrm{Mg} / \mathrm{l}$ at Site 1 . Mean soluble reactive phosphorus $\left(\mathrm{PO}_{4}\right)$ ranged from 7.5 at Site 10 to $18 \mathrm{Mg} / \mathrm{l}$ at Sites 1 and 9.

Cyanobacterial strains were observed under a light microscope and further described with the aid of Camera Lucida, which helped to define taxonomically important characteristics, such as shape of vegetative cell, presence of heterocysts and akinetes (Figures 2, 3, 4, and 5). Results showed that Nostocales, and Chroococcales are major groups in the wetlands of this region. Over the study period, a total of 55 species and 20 different cyanobacteria genera were isolated and documented (Table 2) of which 30 were heterocystous forms and 24 were non-heterocystous. Relative abundance percentages of individual species are shown in Table 2 . Oscillatoriales, Nostocales and Chroococcales species showed the highest relative abundance values. Chroococcus turgidus and Nostoc punctiforme were found in almost all sites except Site 3 and Site 5 respectively. Two species of Haplosiphon were only found in samples from the guest house pond (control), although it is one of the major species observed in rice paddy fields by Das [19]. In terms of frequency of occurrence the genera Anabaena, Chroococcus,

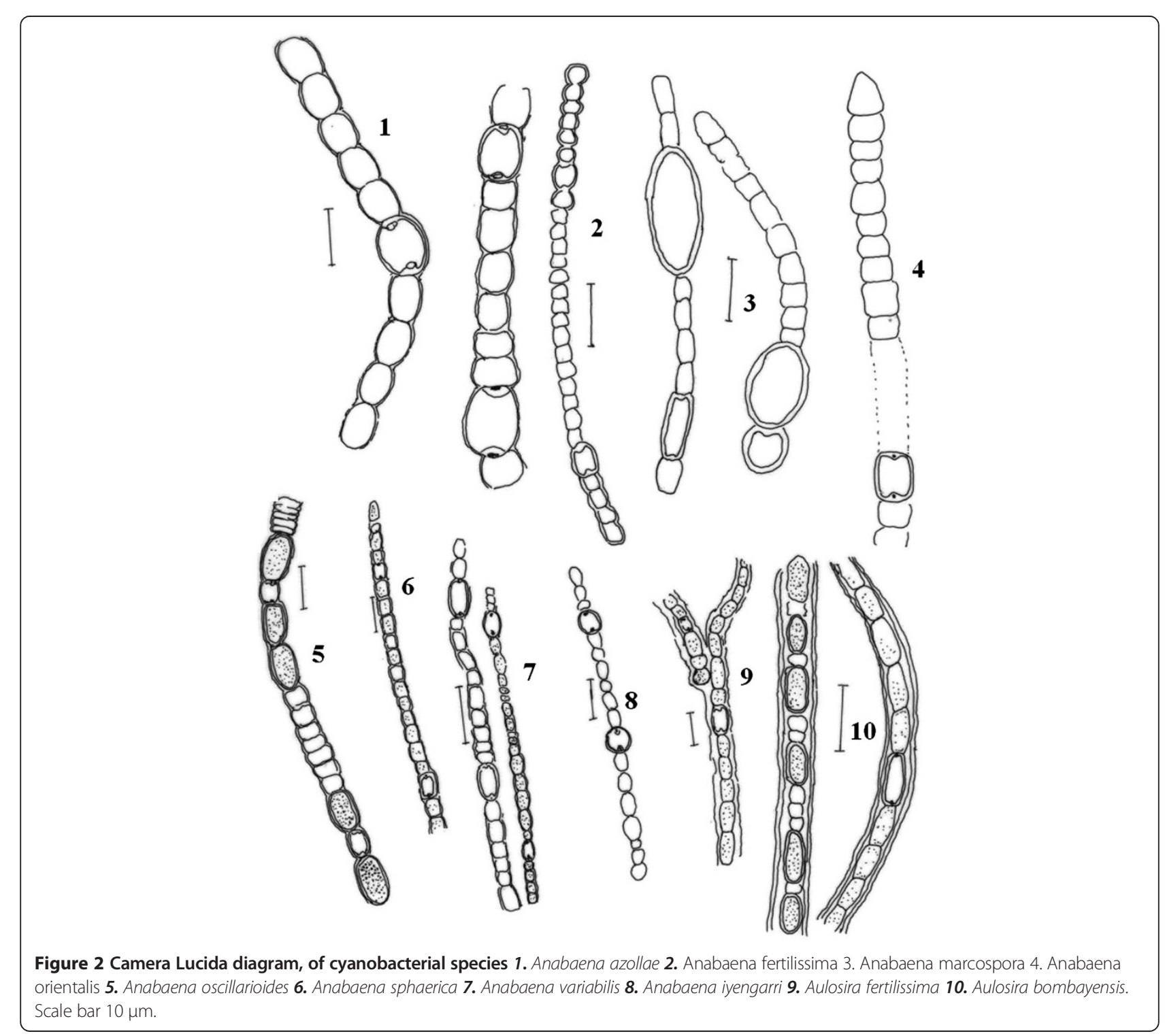




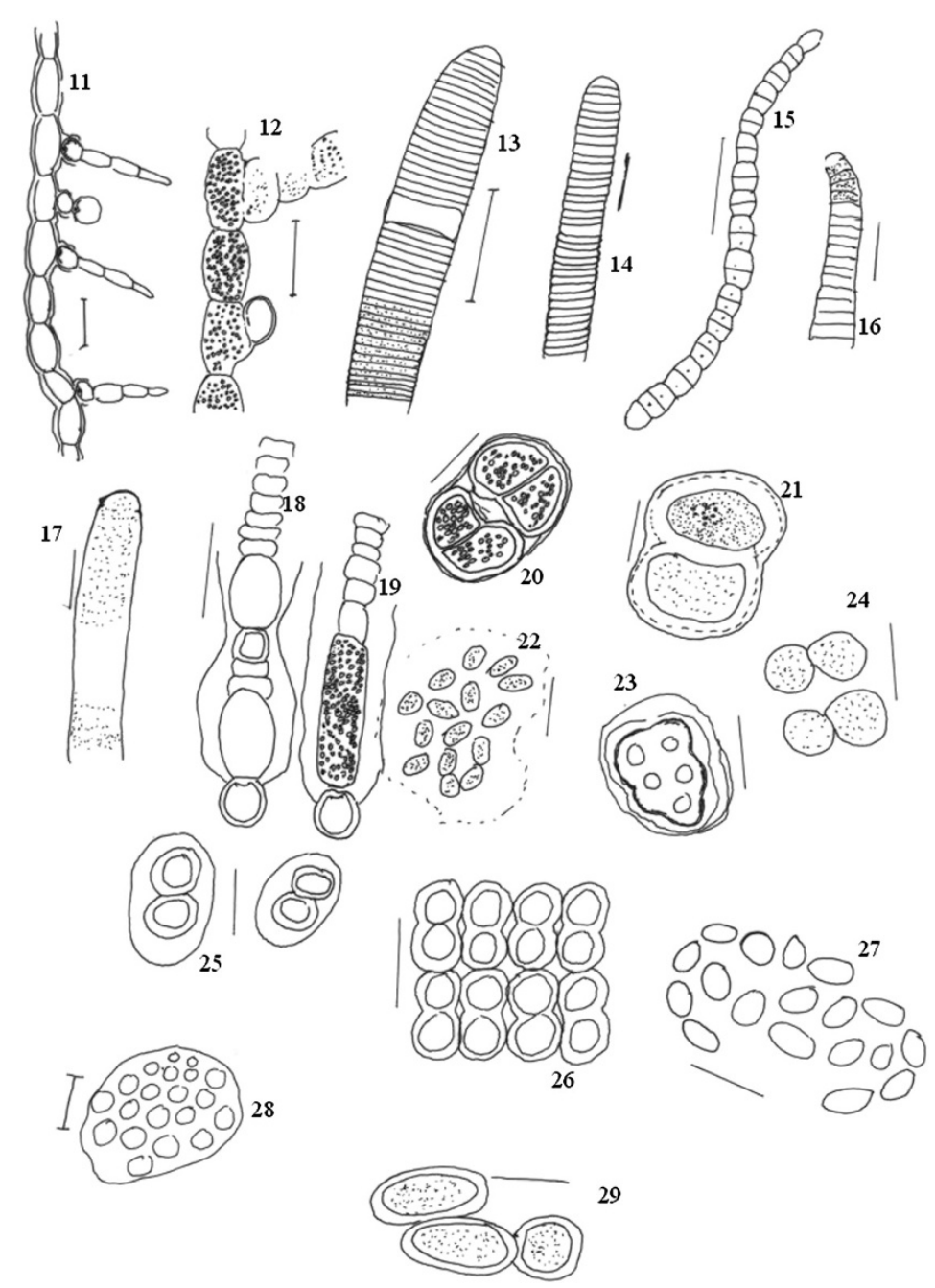

Figure 3 Camera Lucida diagram, of cyanobacterial species 11. Nostochopsis radians 12. Nostochopsis lobatus 13. Oscillatoria simplicissima 14. Oscillatoria jenesis 15. Oscillatoria sp. 16. Oscillatoria princeps 17. Oscillatoria limosa 18. Gloeotrichia sp. 19. Gloeotrichia natans 20. Chroocococcus tanex 21. Chroococcus limneticus 22. Gloeocapsa gelatinosa 23. Gloeocapsa sp. 24. Chroococcus turgidus 25. Gloeocapsa sp. 26. Merismopodia sp. 27. Aphanothece conferta 28. Coelosphaerium sp. 29. Gloeothece rupestris. Scale bar $10 \mu \mathrm{m}$.

Gloeocapsa, Nostoc, Oscillatoria and Phormidium were observed at all sites, while at the other end of the spectrum Coelospherium and Fischerella were only observed in 33\% (Table 3). Presence of Anabaena, Oscillatoria and Chroococcus indicate the polluted values of wetlands.

Diversity index of cyanobacterial populations at the study sites were calculated using the Shannon-Wienner Method (1949) (Table 4). Sites 3, 4, 6, 8 and 10 had indices over 3 (Table 4). Sites 1, 2, 7 and 9 had indices between, 2 and 3 , while Site 5 had the lowest value, i.e. 1.24. The two sites with the lowest diversity, Sites 1 and 5 , also exhibited the lowest mean DO values and the highest mean TSS, TDS and COD values.

Correlation analysis (Table 5) of physicochemical properties of water samples and total cyanobacterial species (TCS) revealed a positive correlation (Figure 6) between dissolved oxygen and TCS $(\mathrm{r}=0.9385 \mathrm{p}<0.01)$, which supports the findings of Muthukumar et al., [1]. In addition, the negative correlations between TCS and TSS, TDS, BOD, and COD, although not significant at the 0.01 level, further suggest that reduced water quality is associated with lower cyanobacterial diversity. By contrast, cyanobacterial abundance or biomass can increase in polluted systems associated with heavy nutrient loads. Kim et al., [22] found a positive correlation between prevalence of cyanobacteria and the levels of pollution in reservoir water, including the following species Anabaena azollae, Anabaena oscillarioides, Aphanothece microscopic, Chroococcus limneticus, Chroococcus turgidus, Chroococcus tenax, Gloeocapsa, Lyngbya, Oscillatoria, Phormidium. The crucial role in physicochemical parameters in defining algal community composition and abundance in agricultural and wetland ecosystems of tropical 

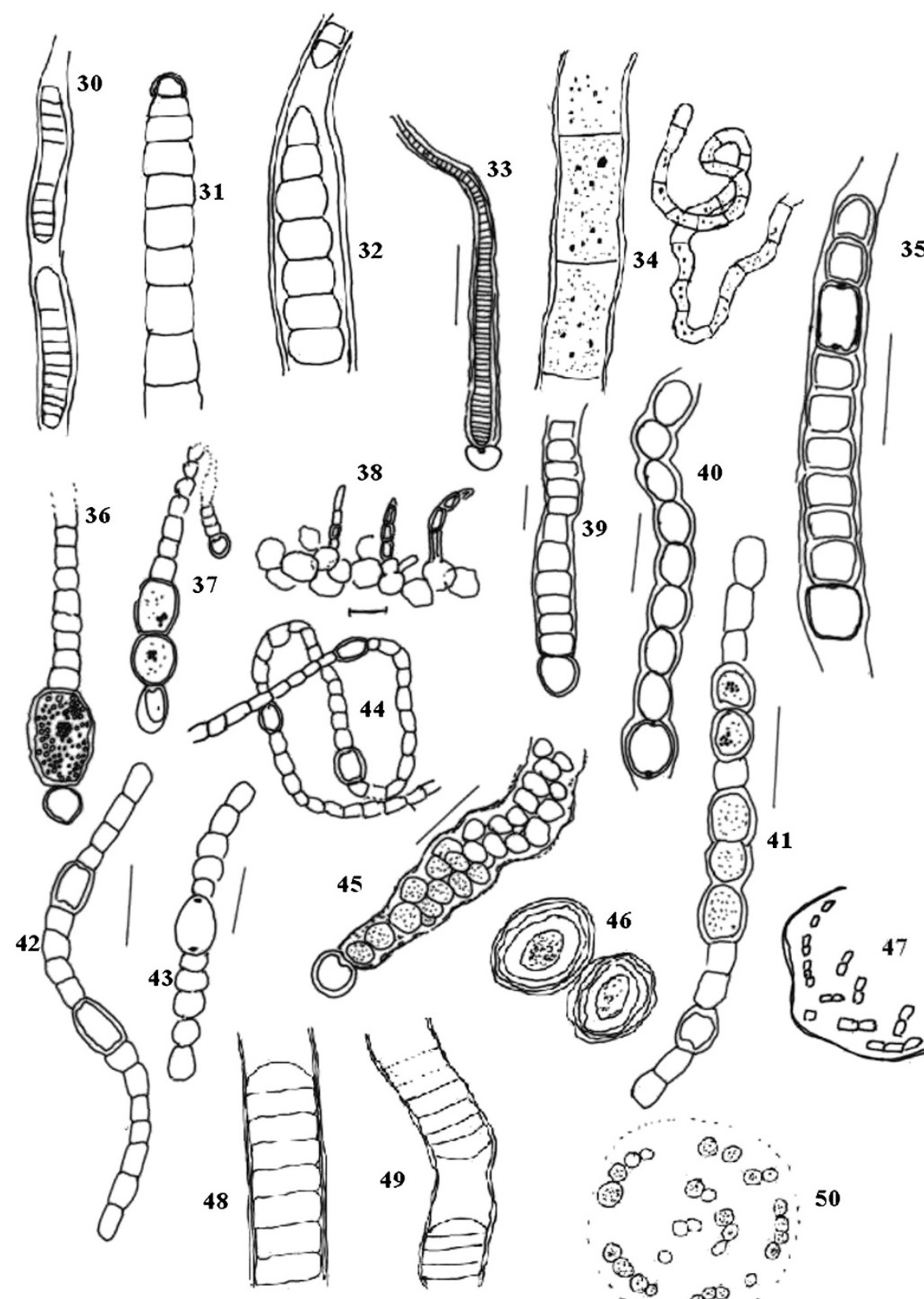

35

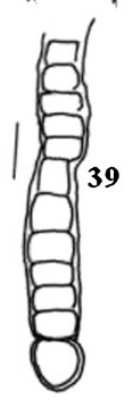

30

38

(1)
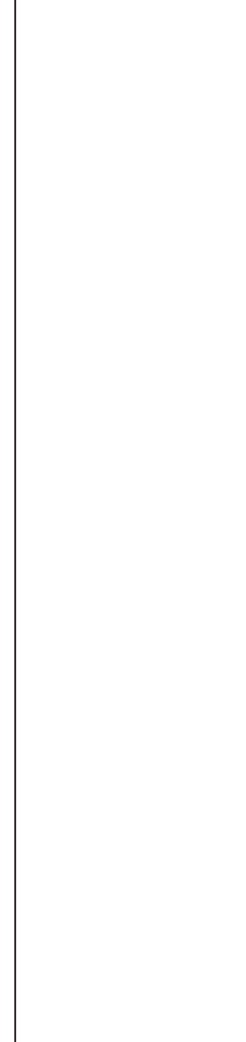

Figure 4 Camera Lucida diagram, of cyanobacterial species 30. Phormidium purpurascans 31. Phormidium 32. Phormidium 33. Calothrix braunii 34. Phormidium sp. 35. Microchaete aequalis 36. Cylindrospermum muscicola 37. Cylindrospermum sp. 38 . Fischerella muscicola 39. Microchaete sp. 40. Microchaete sp. 41. Nostoc spongiforme 42. Nostoc commune 43. Nostoc muscorum 44. Nostoc carneum 45. Nostoc punctiforme 46. Aphanothece microscopica 47. Aphanothece microscopic 48. Lyngbya sp. 49. Lyngbya sp. 50. Chroococcus sp. Scale bar 10 um.

and temperate regions has been examined by a number of researchers (Kohler, [23]; Chellappa et al., [24]; Prasanna et al., [25].

Rapid cyanobacterial growth in the micro aerophilic condition has been observed by Stewart and Parsons [26]. Rai and Kumar [27] did not find heterocystous cyanobacteria in polluted water, although in our study various heterocystous species, including the genera Anabaena, and
Nostoc, were commonly present. Presence of Anabaena, and some other blooming cyanobacteria have been linked to low DO content in eutrophic waterbodies (Moss, [28]; Mbonde et al., [29]. In terms of non-heterocystous taxa, Oscillatoria has been found to be tolerant to polluted water (Singh and Saxena [30]. Our observation of the widespread presence of the non-heterocystous genera Oscillatoria, Phormidium, Gloeocapsa, and Chroococcus corresponds to 

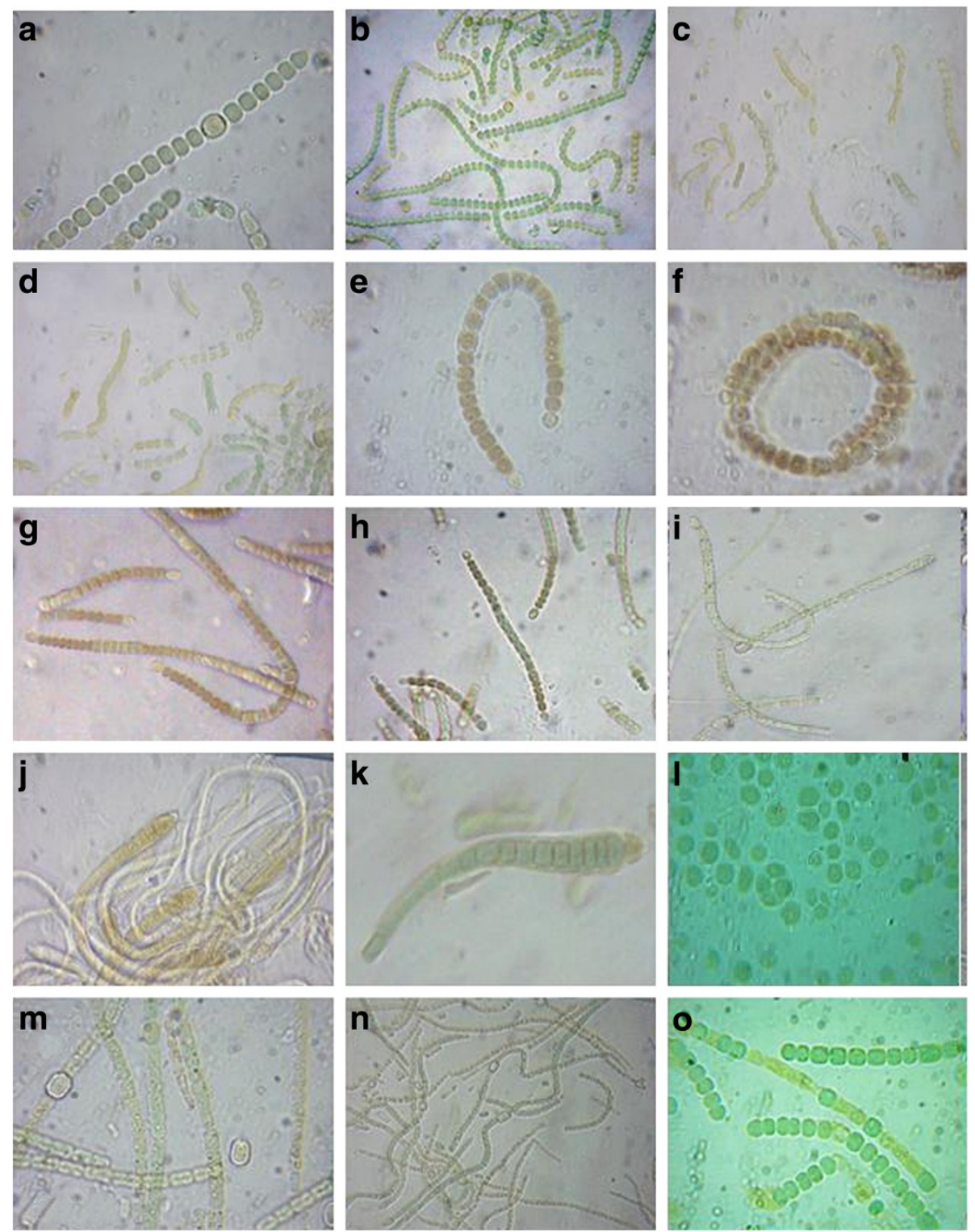

Figure 5 Cyanobacterial strains under microscope: a. Nostoc spongiforme; b. Nostoc spongiforme; c. Nostoc sp.; d. Nostoc sp.; e. Anabaenopsis sp.; f. Anabaena circularis; g. unidentified; h. Anabaena roxburgii; i. Anabaena variabilis j. Calothrix sp.; k. Microchaetae sp.; I. Gleocapsa sp.; m. Nostoc muscorum; n. Anabaena sp.; o. Anabaena sp.

the findings of other wetland systems (Palmer, [31], 1980; Dubey et.al., [32] and Ghadai et al., [13].

\section{Conclusions}

Cyanobacteria are important primary producers at the base of the microbial food web in many aquatic environment. The composition and diversity of cyanobacterial communities can provide insights into changes in water quality. The present study provides a baseline of information on cyanobacterial composition associated with tropical wetland habitats under the influence of significant industrial development. This information can also be used to identify candidate species for use in bioremediation of industrial waste, since the species found in these systems are adapted to the stresses imposed by the components of the waste.

\section{Methods}

\section{Study site}

The study was conducted in different wetlands of Sambalpur districts, Odisha. Nine sampling sites (Figures 1 and 7) were selected from different industrial regions. A Guest house pond at Sambalpur University was selected as a site not directly influenced by industrial development. The sites are as follows: Site1, Paddy field water near 
Table 2 Diversity of Cyanobacteria in different wetlands of Sambalpur

\begin{tabular}{|c|c|c|c|c|c|c|c|c|c|c|c|c|c|c|}
\hline Name of species & Site1 & Site2 & Site3 & Site4 & Site5 & Site6 & Site7 & Site8 & Site9 & Site 10 & FO & RF & RD & $\mathrm{RA}$ \\
\hline Anabaena azolae & + & + & + & + & + & - & + & - & + & + & 80 & 3.08 & 5.81 & 3.60 \\
\hline Anabaena fertilissima & - & + & + & - & - & + & - & - & - & + & 40 & 1.54 & 1.33 & 1.65 \\
\hline Anabaena iyengani & + & + & - & + & - & - & + & + & + & - & 60 & 2.31 & 1.66 & 1.37 \\
\hline Anabaena marcospora & + & - & + & - & - & - & + & - & - & + & 40 & 1.54 & 0.83 & 1.03 \\
\hline Anabaena orientalis & - & + & + & - & - & + & + & - & + & - & 50 & 1.92 & 1.33 & 1.32 \\
\hline Anabaena oscillarioides & + & - & - & + & + & + & - & + & - & + & 60 & 2.31 & 2.49 & 2.06 \\
\hline Anabaena sphaerica & - & - & + & + & - & - & - & - & - & - & 20 & 0.77 & 1.00 & 2.47 \\
\hline Anabaena variabilis & - & + & - & - & - & + & + & - & - & + & 40 & 1.54 & 1.66 & 2.06 \\
\hline Aphanocapsa grevillei & - & - & - & - & - & + & - & + & + & - & 30 & 1.15 & 0.83 & 1.37 \\
\hline Aphanocapsa sp & & + & & + & & & + & & & - & 30 & 1.15 & 0.66 & 1.10 \\
\hline Aphanocapsa sp & + & - & + & - & - & + & + & - & + & + & 60 & 2.31 & 1.99 & 1.65 \\
\hline Aphanothece conferta & + & + & - & + & - & + & - & + & + & - & 60 & 2.31 & 3.32 & 2.74 \\
\hline A. microscopica & + & + & + & - & + & - & - & + & + & - & 60 & 2.31 & 1.33 & 1.10 \\
\hline Aulosira bombayensis & - & - & - & + & - & + & - & - & - & + & 30 & 1.15 & 1.00 & 1.65 \\
\hline Aulosira fertilisima & + & + & - & - & - & - & + & + & + & + & 60 & 2.31 & 2.16 & 1.78 \\
\hline Calothrix braunii & + & - & + & - & + & - & - & - & + & + & 50 & 1.92 & 1.16 & 1.15 \\
\hline Calothrix clavatoides & + & - & - & + & - & + & - & + & - & + & 50 & 1.92 & 0.83 & 0.82 \\
\hline Calothrix javanica & - & + & - & - & - & - & - & + & - & + & 30 & 1.15 & 0.83 & 1.37 \\
\hline Calothrix linearis & + & + & - & - & - & + & - & - & - & + & 40 & 1.54 & 1.99 & 2.47 \\
\hline Calothrix parientina & - & - & + & + & - & + & + & - & - & - & 40 & 1.54 & 1.33 & 1.65 \\
\hline Chrococcus limneticus & + & - & - & - & + & + & - & + & + & - & 50 & 1.92 & 1.33 & 1.32 \\
\hline Chrococcus turgidus & + & + & + & + & - & + & + & + & + & + & 90 & 3.46 & 4.49 & 2.47 \\
\hline Chrocococcus tanex & + & - & + & - & + & - & - & - & + & - & 40 & 1.54 & 2.33 & 2.88 \\
\hline Coleosphaerium sp & + & - & - & - & - & + & - & - & + & - & 30 & 1.15 & 0.66 & 1.10 \\
\hline Cylindrospermum sp & - & - & + & + & - & - & - & - & + & + & 40 & 1.54 & 0.83 & 1.03 \\
\hline C. muscicola & + & - & - & - & - & + & + & + & - & + & 50 & 1.92 & 2.16 & 2.14 \\
\hline Fischerella muscicola & - & - & + & + & - & + & - & - & - & + & 40 & 1.54 & 1.16 & 1.44 \\
\hline Gleocapsa sp & - & - & - & + & + & - & - & + & - & - & 30 & 1.15 & 1.83 & 3.02 \\
\hline Gleocapsa & & + & & & & + & + & + & + & + & 60 & 2.31 & 2.16 & 1.78 \\
\hline Gleocapsa & + & + & + & + & + & - & - & + & + & - & 70 & 2.69 & 4.15 & 2.94 \\
\hline Gleotheceae sp & + & + & - & - & - & - & + & - & + & + & 50 & 1.92 & 2.49 & 2.47 \\
\hline Gleotrichia natans & + & - & - & - & + & - & - & + & + & + & 50 & 1.92 & 1.00 & 0.99 \\
\hline Gleotrichia sp & - & - & + & + & - & + & - & + & + & - & 50 & 1.92 & 1.50 & 1.48 \\
\hline Haplosiphon & - & - & - & - & - & - & - & - & + & + & 20 & 0.77 & 0.50 & 1.23 \\
\hline Haplosiphon sp & - & - & - & - & - & - & - & - & + & + & 20 & 0.77 & 0.50 & 1.23 \\
\hline Lyngbya sp & + & - & + & + & + & - & - & - & - & + & 50 & 1.92 & 1.50 & 1.48 \\
\hline Lyngbya & + & + & - & - & - & + & + & + & + & + & 70 & 2.69 & 3.65 & 2.59 \\
\hline Merismopedia eligans & - & - & - & - & - & - & - & - & + & - & 10 & 0.38 & 0.17 & 0.82 \\
\hline Merismopodia sp & - & + & - & + & - & + & - & + & - & - & 40 & 1.54 & 1.83 & 2.26 \\
\hline Microcheate sp & + & - & - & + & + & - & - & + & - & - & 40 & 1.54 & 2.16 & 2.67 \\
\hline Microcheate aequalis & - & + & - & - & - & + & - & + & - & - & 30 & 1.15 & 1.16 & 1.92 \\
\hline Nostoc carneum & + & - & + & + & + & + & + & - & + & + & 80 & 3.08 & 3.16 & 1.95 \\
\hline Nostoc commune & + & - & - & - & - & + & - & - & - & + & 30 & 1.15 & 1.00 & 1.65 \\
\hline
\end{tabular}


Table 2 Diversity of Cyanobacteria in different wetlands of Sambalpur (Continued)

\begin{tabular}{llllllllllllllll}
\hline Nostoc muscorum & - & - & + & - & - & - & - & + & - & + & 30 & 1.15 & 1.33 & 2.19 \\
Nostoc punctiformae & + & + & + & + & - & + & + & + & + & + & 90 & 3.46 & 2.16 & 1.19 \\
Nostoc spongiformae & + & - & - & + & - & - & - & - & - & + & 30 & 1.15 & 1.00 & 1.65 \\
Nostocopsis radians & - & - & + & - & - & + & - & - & + & - & 30 & 1.15 & 0.83 & 1.37 \\
Nostocopsis sp & + & + & - & + & - & - & - & + & - & - & 40 & 1.54 & 0.83 & 1.03 \\
Oscillatoria limosa & + & - & + & - & + & + & - & - & - & + & 50 & 1.92 & 3.49 & 3.45 \\
Oscillatoria princes & + & + & - & + & - & + & - & + & + & + & 70 & 2.69 & 3.82 & 2.70 \\
Oscillatoria sp & + & + & - & + & - & + & + & - & - & + & 60 & 2.31 & 2.66 & 2.19 \\
Oscillatoria sp & + & - & + & - & - & - & - & + & + & - & 40 & 1.54 & 0.83 & 1.03 \\
Phormidium sp & + & + & + & - & + & + & + & + & - & + & 80 & 3.08 & 3.49 & 2.16 \\
Phormodium & + & - & - & + & + & + & + & + & - & - & 60 & 2.31 & 2.82 & 2.33 \\
Phormodium & - & + & + & + & - & + & - & - & - & + & 50 & 1.92 & 1.50 & 1.48 \\
Total & 33 & 24 & 24 & 26 & 15 & 31 & 19 & 27 & 26 & 33 & &
\end{tabular}

+: present; -: not recorded.

ShyamDRI; Site2, Pond water near Aryan Ispat and steel Pvt. Limited; Site3, In wetland near Viraj Steel Pvt. Ltd; Site4, Stagnant water pond near Kherual bridge of $\mathrm{M} / \mathrm{s}$ Bhusan Power and Steel Ltd.; Site5, Paddy field near M/s Bhusan Power and Steel Ltd.; Site6, Pond near the Rengali WESCO office; Site7, Pond near Debaipali; Site8, Pond near Sason village; Site 9, Pond near Ganesh Nagar; Site 10, Guest House pond at Sambalpur University.

Table 3 Major genera and their relative abundance in the sample

\begin{tabular}{lll}
\hline Genus & Total no of species & Frequency of occurance \\
\hline Anabaena & 8 & 100 \\
Chroococcus & 3 & 100 \\
Gloeocapsa & 3 & 100 \\
Nostoc & 5 & 100 \\
Oscillatoria & 4 & 100 \\
Phormidium & 3 & 100 \\
Aphanothece & 2 & 89 \\
Calothrix & 1 & 22 \\
Lyngbya & 2 & 89 \\
Aphanocapsa & 3 & 78 \\
Aulosira & 2 & 78 \\
Cylindrospermum & 2 & 78 \\
Gloeotrichia & 2 & 78 \\
Microchaete & 2 & 67 \\
Merismopodia & 2 & 56 \\
Gloeothece & 1 & 45 \\
Nostochopsis & 2 & 45 \\
Coelosphaerium & 1 & 33 \\
Fischerella & 1 & 33 \\
\hline
\end{tabular}

Surface grab water samples were collected in bottles from each site for microscopic analysis and isolation of cyanobacterial strains.

\section{Collection of water sample}

Water sample are collected in $250 \mathrm{ml}$ air tight plastic jars. A few rocks from wetlands were collected to examine attached cyanobacteria.

\section{Physicochemical properties of water}

The physicochemical analyses of the water samples were carried out by using standard methods (APHA, [33] and Trivedy and Goel [34].

Isolation and enumeration of cyanobacteria

One $\mathrm{ml}$ water samples were added to agar plates made with $25 \mathrm{ml}$ of sterilized $\mathrm{BG} \pm 11$ medium in petri dishes

Table 4 Occurrence and distribution of cyanobacteria in various locations of Sambalpur, India along with Shannon-Wienner diversity index $(\mathrm{H})$

\begin{tabular}{ccccc}
\hline Location & $\begin{array}{c}\text { Total no } \\
\text { of genera }\end{array}$ & $\begin{array}{c}\text { Non } \\
\text { heterocystous } \\
\text { forms }\end{array}$ & $\begin{array}{c}\text { Heterocystous } \\
\text { forms }\end{array}$ & $\begin{array}{c}\text { Shannon } \\
\mathbf{( H )}\end{array}$ \\
\hline Site 1 & 17 & $\mathbf{1 8}$ & 15 & 2.28 \\
Site 2 & 14 & $\mathbf{1 1}$ & $\mathbf{1 1}$ & $\mathbf{2 . 4 9}$ \\
Site 3 & 13 & $\mathbf{1 0}$ & $\mathbf{1 2}$ & $\mathbf{3 . 0 1}$ \\
Site 4 & 15 & $\mathbf{1 0}$ & $\mathbf{1 3}$ & $\mathbf{3 . 0 3}$ \\
Site 5 & 11 & $\mathbf{1 0}$ & $\mathbf{5}$ & $\mathbf{1 . 2 4}$ \\
Site 6 & 17 & $\mathbf{1 4}$ & $\mathbf{1 5}$ & $\mathbf{3 . 4}$ \\
Site 7 & 11 & $\mathbf{7}$ & $\mathbf{1 0}$ & $\mathbf{2 . 8 2}$ \\
Site 8 & 16 & $\mathbf{1 5}$ & $\mathbf{1 1}$ & $\mathbf{3 . 1 9}$ \\
Site 9 & 14 & $\mathbf{7}$ & $\mathbf{9}$ & $\mathbf{2 . 8 7}$ \\
Site 10 & 17 & $\mathbf{1 1}$ & $\mathbf{2 2}$ & $\mathbf{3 . 3 5}$ \\
\hline
\end{tabular}


Table 5 Correlation co-efficient analysis of physicochemical properties of water and total cyanobacterial species (TCS)

\begin{tabular}{|c|c|c|c|c|c|c|c|c|c|}
\hline & $\mathrm{pH}$ & TSS & TDS & DO & BOD & COD & $\mathrm{NO}_{3}$ & $\mathrm{PO}_{4}$ & $\mathrm{TCS}$ \\
\hline $\mathrm{pH}$ & 1 & & & & & & & & \\
\hline TSS & 0.620829 & 1 & & & & & & & \\
\hline TDS & 0.513552 & $0.947356^{*}$ & 1 & & & & & & \\
\hline DO & -0.51899 & -0.943732 & -0.908277 & 1 & & & & & \\
\hline BOD & 0.535549 & $0.828902^{*}$ & 0.827283 & -0.844629 & 1 & & & & \\
\hline COD & 0.321332 & $0.783196^{*}$ & 0.804691 & -0.830509 & $0.93978^{*}$ & 1 & & & \\
\hline $\mathrm{NO}_{3}$ & 0.158125 & 0.640212 & 0.703164 & -0.709126 & 0.75499 & $0.880077^{*}$ & 1 & & \\
\hline $\mathrm{PO}_{4}$ & 0.338464 & 0.73854 & $0.893818^{*}$ & -0.784829 & 0.66081 & 0.694318 & 0.717146 & 1 & \\
\hline TCS & -0.01215 & -0.331114 & -0.360616 & $0.938492^{*}$ & -0.05977 & -0.00745 & 0.130953 & -0.39107 & 1 \\
\hline
\end{tabular}

* significant $\leq 0.01$.

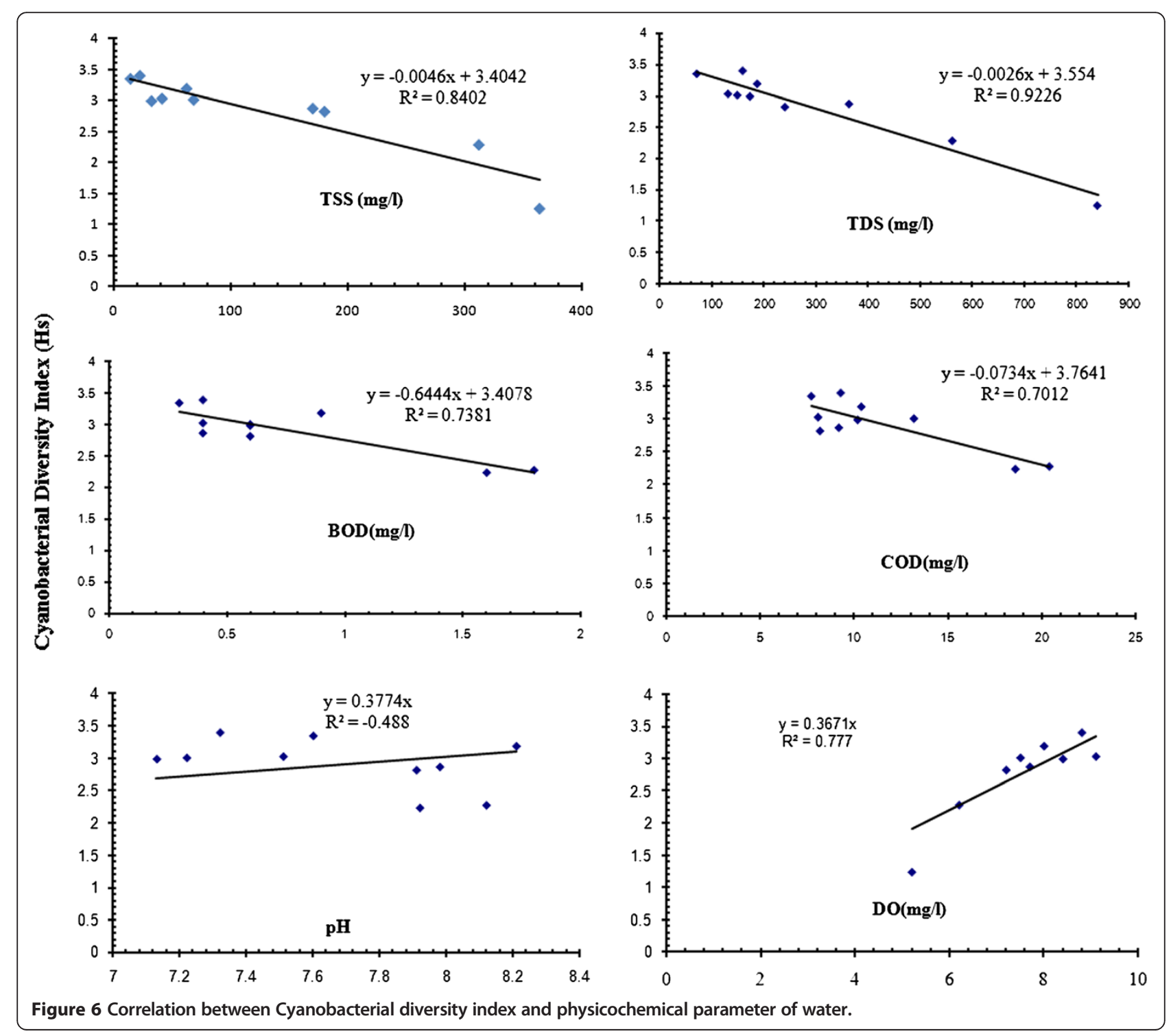




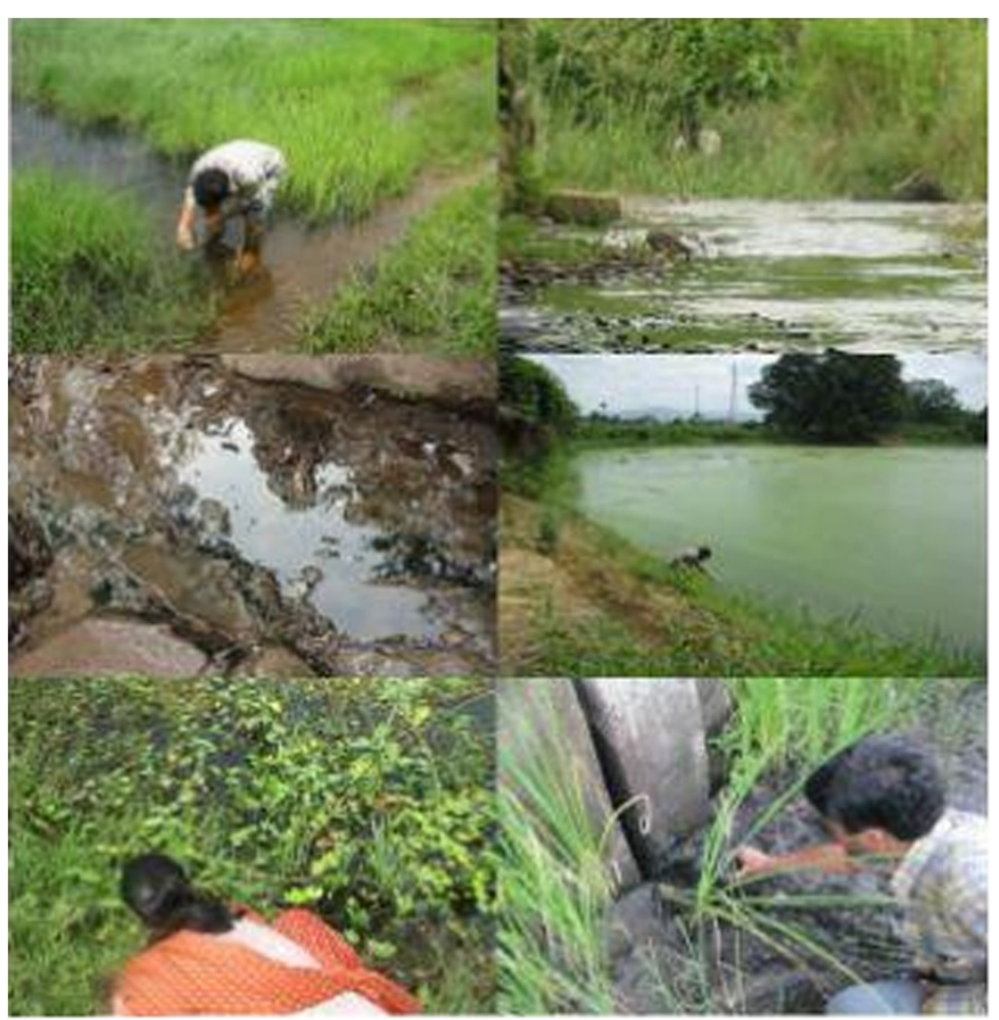

Figure 7 Water sample collected from different wetland of Sambalpur, Odisha, India.

(Rippka et al., [35] The dishes were kept under $7.5 \mathrm{~W} /$ $\mathrm{m}^{2}$ light intensity at $25 \pm 0.5^{\circ} \mathrm{C}$ in a culture room. After 10-12 days of incubation, algal colonies appeared on the agar plates. The number of colonies of each species were recorded (CFU), after microscopic observation. Colonies were then isolated and spread on to fresh agar plates. After development, colonies appearing in agar plates were examined microscopically and transferred to agar slants. This process was repeated until individual pure colonies were obtained free from any contamination.

\section{Microscopic analysis}

Isolated cyanobacterial strains were observed under microscope MLX-TR. For morphometric analysis Camera Lucida Drawings was done and data related to trichome shape, filament colour, akinete and heterocyst shape, size, position, number recorded. Identification of cyanobacteria was done using the keys given by Desikachary [36] and Komarek and Anagnostidis [37,38].

\section{Data analysis}

a. Frequency of Occurance:

$$
\begin{aligned}
F O= & \frac{\text { Number of sample containing the species }}{\text { Total no sample examined }} \\
& \times 100
\end{aligned}
$$

b. Relative Frequency:

$$
\begin{aligned}
R F= & \frac{\text { Number of sample containing a species }}{\text { Total no of occurance of all the species }} \\
& \times 100
\end{aligned}
$$

c. Relative Density:

$$
\begin{aligned}
R D= & \frac{\text { Number of } C F U \text { of a species in all samples }}{\text { Total no of CFU all the species in all the samples }} \\
& \times 100
\end{aligned}
$$

d. Relative abundance:

The relative abundance of a particular cyanobacteria type was calculated by employing the formula:

$$
\begin{aligned}
R A= & \frac{\text { Number of samples containing the species }}{\text { Total no of occurance of all the species }} \\
& \times 100
\end{aligned}
$$

e. Diversity index: Cyanobacterial diversity in different sites has been calculated by Shannon's Diversity index (Shannon Wienner [39] as per the following formula

$$
H s=-\sum_{i=1}^{S}(P i)(\ln P i)
$$

Where,

Hs- diversity in the sample S species or kinds 
S- the Number of Species in the Sample $\mathrm{Pi}$ - relative abundance of $\mathrm{i}^{\text {th }}$ species or Kind measures, $n_{\mathrm{i}} / \mathrm{N}$

$\mathrm{N}$ - total no of individuals of all kinds $\mathrm{n}_{\mathrm{i}}$ - no of individual of $\mathrm{i}^{\text {th }}$ species

f. Correlation coefficient were calculated as per [40], using Microsoft Excel 2007 Package and analysed for their significant using Pearson's table

\section{Abbreviations}

TSS: Total suspended solids; TDS: Total dissolve solids; DO: Dissolve oxygen; BOD: Biological oxygen demand; COD: Chemical oxygen demand; TCS: Total cyanobacterial species; CFU: Colony forming unit.

\section{Competing interests}

The authors declare that they have no competing interests.

\section{Authors' contributions}

PRD performed the experiments, SB calculated results, prepared the Table, Graph, Diagram, Statistical analysis and composed the Draft for manuscript in consultation with BN. BN designed the experiment, SB analysed and interpreted data and result, modified the manuscript in final form. BN planned the project, was involved in acquisition of funds. BN selects the sites of sample collections. All the authors read and approved the final manuscript.

\section{Acknowledgement}

The authors are grateful to UGC, New Delhi For financial assistance.

Received: 1 June 2012 Accepted: 1 July 2013

Published: 12 July 2013

\section{References}

1. Muthukumar C, Muralitharan G, Vijayakumar R: Cyanobacterail biodiversity from different freshwater ponds of Thanjavur, Tamilnadu (India). Acta Botanica Malcitana 2007, 32:17-25.

2. Bhattacharyya S, Nayak B, Choudhury NK: Response of Diaztoropic Cyanobacteria Nostoc carneum under pesticide and UV-B stress. Chemosphere 2011, 84:131-135

3. Adhikary SP: Utilization of region specific cyanobacteria as biofertilizer for rice-a case study from Orissa; Conference paper. Biotechnol Micr Sustainable Utilization 2002:47-56.

4. Bhatnagar A, Makandar MB, Garg MK, Bhatnagar M: Community structure and diversity of cyanobacteria and green algae in the soils of Thar Desert (India). J Arid Environ 2008, 72:73-83.

5. Deepa P, Jeyachandran S, Manoharan C, Vijayakumar S: Survey of Epilithic Cyanobacteria on the temple walls of Thanjavur District, Tamilnadu, India. World J Sci Technol 2011, 1(9):28-32.

6. Palleyi S, Kar RN, Panda CRJ: Influence of water quality on the biodiversity of phytoplankton in Dhamra river Estuary of Odisha Coast, Bay of Bengal. App/ Sci Environ Manage 2011, 15(1):69-74.

7. Aharon O, Danny I, Hindiyeh Muna Y, Malkawi Hanan I: Morphological, phylogenetic and physiological diversity of cyanobacteria in the hot springs of Zerka Ma'in Jordan. BioRisk 2009, 3:69-82.

8. Jiri $K$, Josef $E$, Ondlej $K$ : Diversity of the cyanobacterial microxora of the northern part of James Ross Island, NW Weddell Sea, Antarctica. Polar Biol 2008, 31:853-865.

9. Rivas M, Garcia C, Liberona JL, Lagos N: Biochemical characterization and inhibitory effect of dino physistoxin-1, okadaic acid amd microcystine LR or Protein Phosphatase 2a purified from the mussel mytilus chilensis. Biol Res 2000, 33:197-206.

10. Garcia C, Pereira P, Valle L, Lagos N: Quantification of diarrhetic shellfish poisoning toxins in Chilean Mussel using Pyrenyldiazomethane as fluorescent labeling reagent. Biol Res 2003, 36:171-182.

11. Komárek J: Cyanobacterial taxonomy: current problems and prospects for the integration of traditional and molecular approaches. Algae 2006, 21(4):349-375.
12. Hecky RE: The eutrophication of Lake Victoria. Verhandlungen Intyernationale Vereinigung fur Theoretische and Angewandte Limnologia 1993, 25:39-48.

13. Ghadai AK, Sahoo S, Raut S: Agroecological Survey of cyanobacterial population in paddy field soils of Gunupur. Int J Agric Sci 2010, 2(2):28-32.

14. Dey HS, Tayung K, Bastia AK: Occurrence of nitrogen-fixing cyanobacteria in local rice fields of Orissa, India. Ecoprint 2010 $17: 77-85$

15. Dey HS, Bastia AK: Cyanobacterial Flora from rice growing areas of Mayurbhanj. Plant SC Res 2008, 30(1\&2):22-26.

16. Prasanna R, Nayak S: Influence of diverse rice soil ecologies on cyanobacterial diversity and abundance. Wetlands Ecol Managmt 2007, 15:127-134.

17. Sahu JK: Growth and nitrogen fixation of cyanobacteria from rice fields of Puri district, Orissa. Adv Plant Sci 2000, 13(1):47-50.

18. Dash PK, Mohapatra PK, Kar M: Diversity of cyanobacteria from freshwater bodies of similipal biosphere reserve, Orissa, India. E-Planet 2011, 9(1):1-14.

19. Das MK: Cyanobacterial diversity in the rice field soils of Sambalpur Districts of Orissa. Phykos 2002, 41(1\&2):71-76.

20. Nayak S, Prasanna R: Soil pH and its role in cyanobacterial abundance and diversity in rice field soils. Appl Ecol Environ Res 2007, 5:103-113.

21. Verma J, Mohanty RC: Phytoplankton and its correlation with certain physiochemical parameters of Danmukundpur pond. Poll Res 1995, 14(2):233-242.

22. Kim JB, Moon MS, Lee DH, Lee ST, Bazzicalupo M, Kim CK: Comperative analysis of cyanobacterial communities from polluted reservoirs in Korea. J Microbiol 2004, 42:181-187.

23. Köhler J: Origin and succession of phytoplankton in a river-lake (Spree, Germany). Hydrobiologia 1994, 289:73-83.

24. Chellappa Naithirithi T, Costa M, Maria A: Dominant and co-existing species of Cyanobacteria from a Eutrophicated reservoir of Rio Grande do Norte State, Brazil. Acta Oecologica 2003, 24:S3-S10.

25. Prasanna R, Jaiswal P, Shrikrishna J, Joshi M, Nain L, Rana A, Shivay YS: Evaluating the rizo cyanobacteria as inoculants for rice and wheat. J Agric Technol 2012, 1:157-171.

26. Stewart WDP, Parsons MW: Effect of aerobic and anaerobic conditions on growth and metabolism of bluegreen algae. Proc Roy Soc Bok 1970, 175:293-311.

27. Rai LC, Kumar HD: Systematic and ecological studies on algae of some habitats polluted with fertilizer factory effluent. Nova Hedwigia 1976, 27:805-813.

28. Moss B: Ecology of freshwaters, man and medium, past to future. 3rd edition. Oxford: Blackwell Science Ltd; 1998.

29. Mbonde ASE, Shayo S, Sekadende BC, Lyimo TJ: Phytoplankton species diversity and abundance in the near shore waters of Tanzanian side of Lake Victoria. Tanz I Sci 2004, 30(1):71-81.

30. Singh VP, Saxena PN: Preliminary studies on algal succession in raw and stabilized sewage. Hydrobiologia 1969, 34:503-512.

31. Palmer CM: Composite rating of algae tolerating organic pollution. British Phycol Bull 1969, 5:78-92.

32. Dubey SK, Dubey J, Viswas AJ, Tiwari P: Studies on Cyanobacterial biodiversity in paper mill and pharmaceutical industrial effluents. British Biotechnol J 2011, 1(3):61-67.

33. Clesceri LA, Greenberg EA, Eaton DA: Standard Methods for the Examination of Water and Wastewater. 20th edition. Washington DC: APHA American Public Health Association; 1998.

34. Trivedy RK, Goel PK: Chemical and biological methods for water pollution studies. Environmental publication. Karad. tropical. Revue d'Hydrobiologie Tropicale 1986, 26:219-228.

35. Rippka R, Deruelles J, Waterbury JB, Herdman M, Stanier RY: Generic assignments, strain histories and properties of pure cultures of cyanobacteria. J Gen Microbiol 1979, 111:1-61.

36. Desikachary TV: Cyanophyta. New Delhi: Indian Council of Agricultural Research; 1959:686.

37. Komárek J, Anagnostidis K: Cyanoprokaryota-1. Teil/1st Part: Chroococcales. In Süsswasserflora vonMitteleuropa 19/1. Edited by Ettl H, Gärtner G, Heynig H, Mollenhauer D. Heidelberg: Elsevier/Spektrum; 1998. 
38. Komárek J, Anagnostidis K: Cyanoprokaryota-2.Teil/2nd Part:

Oscillatoriales. In Süsswasserflora vonMitteleuropa 19/2. Edited by Büdel B,

Krienitz L, Gärtner G, Schagerl M. Heidelberg: Elsevier/Spektrum; 2005.

39. Shannon CE: A mathematical theory of communication. Bell Syst Tech $J$ 1949, 27:379-423. 623-656.

40. Wechsler D: Wechsler individual achievement test. 2nd edition. San Antonio, Texas: Pearson; 2005.

doi:10.1186/2046-9063-9-14

Cite this article as: Deep et al:: Cyanobacteria in wetlands of the

industrialized Sambalpur District of India. Aquatic Biosystems 2013 9:14.

\section{Submit your next manuscript to BioMed Central} and take full advantage of:

- Convenient online submission

- Thorough peer review

- No space constraints or color figure charges

- Immediate publication on acceptance

- Inclusion in PubMed, CAS, Scopus and Google Scholar

- Research which is freely available for redistribution 